Рекомендована д. фрармац. наук, профр. Т. А. Грошовим

УДК 651.1:378:005.6.

DOI 10.11603/2312-0967.2016.3.6830

\title{
НАУКОВО-ТЕОРЕТИЧНЕ ОБҐРУНТУВАННЯ МЕТОДОЛОГІЧНОГО КОНЦЕПТУ ПОБУДОВИ СИСТЕМИ ЯКОСТІ ВИЩОЇ ФАРМАЦЕВТИЧНОЇ ОСВІТИ
}

\author{
(c) А. В. Кайдалова, О. В. Посилкіна \\ Національний фрармацевтичний університет, Харків
}

Резюме: у статті здійснено науково-теоретичний аналіз підходів та обґрунтування методологічного концепту побудови та функціонування системи якості вищої фрармацевтичної освіти.

Ключові слова: система якості вищої фармацевтичної освіти, методологічний концепт, наукові підходи до забезпечення якості.

Вступ. Входження України у світове наукове та освітянське співтовариство, суттєві перетворення в системі національної освіти та її інтеграція в європейський простір торкнулись і вищої фрармацевтичної освіти в контексті переосмислення та перебудови управління та забезпечення якості освітнього процесу.

Якість освіти $€$ необхідною передумовою становлення та розвитку фрахівців фрармацевтичного сектора, їх здатності бути конкурентоспроможними на ринку праці, розвиватися та працювати за нових умов.

Одним із перспективних напрямів вирішення проблем якості фрармацевтичної освіти є побудова та належне функціонування системи якості вищої фармацевтичної освіти (СЯВФО), що сприятиме забезпеченню високого рівня підготовки у вищих навчальних закладах (ВН3) фрахівців нової генерації, здатних швидко реагувати на зміни та виклики часу. СЯВФО сприятиме підвищенню рейтингу фрармацевтичних та медичних ВН3, які здійснюють підготовку фрахівців фармацевтичної галузі, на світовому науковому та освітньому просторі.

Окремі методологічні аспекти щодо якості вищої фрармацевтичної освіти розглядаються в наукових публікаціях вітчизняних та зарубіжних вчених. Так, напрями рефрормування вищої фармацевтичної освіти 3 урахуванням тенденцій світового освітнього простору за умов Болонського процесу висвітлюються у роботах Т. Грошового, Л. Кайдалової, В. Кременя, С. Огарь, В. Черних. Зокрема в центрі уваги авторів Л. Галій, л. Кайдалової, А. Котвіцької, В. Толочка, В. Черниха насамперед знаходяться дослідження сутності й інструментів компетентнісного підходу. 3. Мнушко, А. Немченко, В. Толочко акцентують увагу у своїх дослідженнях на удосконаленні системи оцінки підготовки фрахівців фрармацевтичної галузі. Сучасні методичні підходи забезпечення належної якості освітнього процесу представлені у роботах А. Вербицкий, В. Зінченко, В. Лозова, С. Масич, Ю. Шапран та ін.
Проведений аналіз дозволив зробити висновок, що не зважаючи на значну кількість публікацій з питань якості фрармацевтичної освіти, на сьогодні залишається актуальною проблема обґрунтування наукових принципів і загальних методологічних підходів до належного забезпечення побудови і фрункціонування цілісної СЯВФО.

Це, у свою чергу, потребує опрацювання сучасних наукових підходів, які є інструментом управління якістю у вищій освіті, у т. ч. і фрармацевтичної, і які можуть розглядатися як методологічне підґрунтя цієї системи

Метою статті є обґрунтування методології фрормування СЯВФО як сукупності взаємопов'язаних наукових принципів, які дозволяють реалізувати ії мету і забезпечити ефрективне фрункціонування.

Результати й обговорення. Проведені дослідження проблеми забезпечення якості у вищій фрармацевтичній освіти дозволяють стверджувати, що проектування (моделювання або побудова) СЯВФО повинне ґрунтуватися на вивченні та врахуванні вітчизняного та зарубіжного досвіду, теоретичному обґрунтування методологічного концепту, узагальненні й визначенні наукових підходів, необхідних для побудови та ефективного фрункціонування СЯВФО.

На сьогодні в системі вищої освіти відома значна кількість різних методологічних підходів, які покладені в основу освітнього процесу. Серед традиційних методологічних підходів слід визначити: системний, діяльнісний, комплексний, особистісно-орієнтований, особистісно-діяльнісний та ін., а серед нових наукових підходів, які тільки починають активно застосовуватись у вітчизняній системі вищої освіти - контекстний, персонісрікований, ергономічний та ін.) [1-11].

Наступним кроком нашого дослідження став аналіз сутності наукових підходів до забезпечення якості вищої освіти, 3 метою обґрунтування доцільності їх застосування при побудові СЯВФО (табл. 1).

ISSN 2312-0967. Фармацевтичний часопис. 2016. № 3 
Таблиця 1. Аналіз наукових підходів, застосовуваних для забезпечення якості вищої освіти

\begin{tabular}{|c|c|}
\hline Підходи & Сутність підходів \\
\hline Контекстний [1] & $\begin{array}{l}\text { Об’єднання теоретичної та практичної підготовки майбутніх фахівців, органічний } \\
\text { зв’язок отриманих знань із майбутньою професійною діяльністю }\end{array}$ \\
\hline Діяльнісний [2] & Управління ВНЗ як цілеспрямованою активною взаємодією суб’єктів \\
\hline Ситуаційний [2] & $\begin{array}{l}\text { Визначення ситуаційних розбіжностей між системами й усередині них і визначення } \\
\text { найбільш значимих змін ситуації та їхніх впливів на ефективність системи }\end{array}$ \\
\hline Репутаційний [3] & Формування механізму оцінки професійних освітніх програм та навчальних закладів в цілому \\
\hline Результативний [5] & Вимірювання кількісних показників діяльності ВНЗ \\
\hline Соціокультурний [6] & $\begin{array}{l}\text { Визначення рівня загальної культури НПП та здобувачів освіти, } \\
\text { соціальна компетентність НПП }\end{array}$ \\
\hline $\begin{array}{l}\text { Особистісно- } \\
\text { орієнтований [2] }\end{array}$ & $\begin{array}{l}\text { Визначення особистісного рівня здобувачів освіти та оцінка рівня компетентності щодо } \\
\text { очікувань та вимог споживачів }\end{array}$ \\
\hline $\begin{array}{l}\text { Критеріально- } \\
\text { оріентований [2] }\end{array}$ & $\begin{array}{l}\text { Оцінка рівня навчальних досягнень здобувачів освіти відповідно до встановлених } \\
\text { компетностей, визначених у галузевих стандартах вищої освіти }\end{array}$ \\
\hline $\begin{array}{l}\text { Нормативно- } \\
\text { орієнтований [2] }\end{array}$ & $\begin{array}{l}\text { Визначення відповідності освітньої діяльності вимогам національного законодавства, } \\
\text { рекомендаціям міжнародних стандартів }\end{array}$ \\
\hline Гуманістичний [3] & $\begin{array}{l}\text { Врахування інтересів здобувачів освіти при розробці методик навчання, формуванні } \\
\text { змісту освітніх програм. } \\
\text { Актуалізація мотиваційних ресурсів навчання, розвиток навичок, самоосвіти }\end{array}$ \\
\hline Синергетичний [5] & $\begin{array}{l}\text { Спрямованість дій основних елементів системи для посилення ефективності } \\
\text { функціонування всієї системи }\end{array}$ \\
\hline Середовищний [3] & $\begin{array}{l}\text { Формування професійної компетентності фахівця } 3 \text { урахуванням змін та впливу } \\
\text { освітнього середовища }\end{array}$ \\
\hline Детермінаційний [5] & $\begin{array}{l}\text { Забезпечення розвитку системи професійної підготовки фахівців на основі виявлення } \\
\text { причинно-наслідкових зв'язків, умов, чинників, джерел її розвитку й функціонування }\end{array}$ \\
\hline $\begin{array}{l}\text { Персоніфікований } \\
\text { [3] }\end{array}$ & $\begin{array}{l}\text { Реалізація визначених цілей у формуванні компетентностей фахівця за допомогою } \\
\text { активних педагогічних технологій }\end{array}$ \\
\hline Акмеологічний [2] & Постійне вдосконалення власного професіоналізму та самореалізація здобувачів освіти \\
\hline Комплексний [2] & Обгрунтування напрямів розвитку освітнього процесу в їх взаємодії \\
\hline Фасилітаційний [3] & $\begin{array}{l}\text { Використання різноманітних стилів, методів, форм } \begin{array}{c}\text { навчання, співробітництво } \\
\text { викладача, здобувачів освіти та практичних фахівців (роботодавців) }\end{array}\end{array}$ \\
\hline Інформаційний [2] & Використання інформаційних технологій в професійній підготовці фахівців \\
\hline $\begin{array}{l}\text { Професіографічний } \\
\text { [4] }\end{array}$ & $\begin{array}{l}\text { Реалізація певного комплексу вимог для визначених компетентностей майбутніх } \\
\text { фахівців для професійної діяльності }\end{array}$ \\
\hline Рефлексивний [2] & $\begin{array}{l}\text { Створення розвивальних ситуацій, що активізують рефлексію (самосвідомість) } \\
\text { здобувачів освіти та використання набутих умінь в пристосуванні до ситуації }\end{array}$ \\
\hline $\begin{array}{l}\text { Партисипативно- } \\
\text { інтерактивний [3] }\end{array}$ & Розвиток та взаємодія здібностей та особистісних ресурсів здобувачів освіти \\
\hline Герменевтичний [2] & делюванні майбутньої діяльності \\
\hline Інноваційний [5] & Застосування інноваційних технологій в освітньому процесі \\
\hline Ресурсний [6] & Виділення та освоєння необхідних ресурсів для підготови компетентних фахівців \\
\hline Інституційний [5] & $\begin{array}{l}\text { ормування та взаємодія вимог ринку освітніх послуг, освітніх стандартів, норм џ } \\
\text { ормування професійних компетенцій майбутніх фахівців }\end{array}$ \\
\hline Мотиваційний [3] & Формування внутрішньої та зовнішньої мотивації та самомотивації здобувачів освіти \\
\hline Праксеологічний [2] & $\begin{array}{l}\text { Вирішення завдань та цілей вищої освіти з найменшими ресурсними витратами. } \\
\text { Управління освітнім процесом через аналіз та самооцінку }\end{array}$ \\
\hline Технологічний [3] & Організація освітнього процесу із застосуванням інноваційних педагогічних технологій та \\
\hline Інтегративний [7] & Інтеграція різних видів діяльності в процесі теоретичного і практичного навчання \\
\hline Системний [8] & $\begin{array}{l}\text { Сукупність міжсистемних зв’язків і взаємодії та взаємозумовлених елементів } \\
\text { зовнішнього середовища та внутрішньої структури ВНЗ }\end{array}$ \\
\hline Процесний [9] & Визначення освітньої системи як сукупності процесів \\
\hline $\begin{array}{l}\text { Компетентнісний } \\
{[10-11]}\end{array}$ & Обгрунтування рівня підготовки НПП та вимоги до компетеностей майбутніх фахівців \\
\hline Аксіологічний [12] & істу СЯВФО \\
\hline
\end{tabular}

ISSN 2312-0967. Pharmaceutical review. 2016. № 3 
Як вже зазначалося, у межах кожного наукового підходу нами було опрацьовано його сутність. Так, відповідно до контекстного підходу підготовка фрахівців відзначається максимальним наближенням змісту і фрорм навчання до професійної діяльності фрахівця; під час навчального процесу відтворюються реальні зв'язки і стосунки, вирішуються конкретні профресійні завдання. Контекстний підхід забезпечує об'єднання теоретичної та практичної підготовки майбутніх фрахівців, органічний зв'язок отриманих знань із майбутньою професійною діяльністю [1].

Ситуаційний підхід дозволяє визначити основні змінні, їхній вплив на якість вищої фрармацевтичної освіти й ефективність управління системою підготовки фрахівців. Особистісно-орієнтований підхід спрямований на врахування особистісного рівня здобувача освіти та визначення оцінки результатів відносно до очікувань та вимог споживачів [2].

Гуманістичний підхід сприяє реалізації в практиці підготовки фрахівців таких ключових принципів, як врахування і пріоритет інтересів здобувачів освіти при розробці методик навчання, фрормування змісту освітніх програм, творчих проектів; взаємоповаги викладачів і здобувачів освіти, прийнятті рішень між усіма учасниками освітнього процесу; актуалізація мотиваційних ресурсів навчання, розвиток навичок, самоосвіти тощо [3].

Середовищний підхід передбачає опосередковане управління процесом формування професійної компетентності фрахівців і являє собою систему дій суб'єкта управління (здобувачів освіти) з освітнім середовищем, спрямовану на перетворення іїі в засіб проектування й продукування кінцевого результату - фрормування професійної компетентності фрахівця [3].

Профресіографрічний підхід орієнтує учасників освітнього процесу на результат реалізації певного комплексу вимог до визначених компетенцій майбутніх фрахівців для професійної діяльності. Зазначений підхід дозволяє аналізувати уміння в контексті практичної підготовки фрахівців, які реалізуються у сорері певних професійних знань, умінь та навичок [4].

Інноваційний підхід сприяє створенню інноваційно-творчої атмосфери взаємодії між учасниками освітнього процесу підготовки, фрормування у здобувачів освіти готовності до майбутньої професійної діяльності [5].

Ресурсний підхід визначає виділення та освоєння необхідних ресурсів для розвитку професійної компетентності здобувачів освіти в освітньому процесі [6].

Інтегративний підхід орієнтує на якість вищої освіти і досягнення гарантованого результату навчання, націлений на фрормування особистості майбутнього фрахівця через інтеграцію різних видів діяльності в процесі теоретичного і практичного навчання, максимально наближеного за змістом до умов професійної діяльності; вимагає розробки інтегрованого комплексного навчально- методичного забезпечення [7].

Аналізуючи світовий та вітчизняний досвід у створенні та впровадження системи управління якістю (СУЯ) в організаціях, зокрема у ВН3, встановлено, що певні переваги при побудові СУЯ у ВНЗ мають процесний і системний підходи, які є методологічним підґрунтям ідеології всеохоплюючого менеджменту якості (TQM).

Так, в основу системного підходу покладена парадигма менеджменту якості, заснована на концепції міжсистемних зв'язків і взаємодій, що розглядається як сукупність взаємозбумовлених елементів зовнішнього середовища та внутрішньої структури організації. Реалізація системного підходу у формуванні СЯВФО допомагає розкрити структуру проблеми, взаємозв'язок елементів системи та визначити шляхи ефективного управління якістю у ВНЗ.

Вибір процесного підходу як теоретичного підґрунтя управління якістю вищої освіти зумовлений визначенням освітньої системи як сукупності процесів та необхідності встановлення характеру взаємодії цих процесів, а також управління ними для досягнення необхідних результатів.

Перевага процесного підходу полягає у забезпеченні неперервного контролю зв'язків окремих процесів у межах системи взаємопов'язаних і взаємозумовлених бізнес-процесів, що ґрунтується на реалізації вимог міжнародних стандартів серії ISO 9000-2000. Особлива увага приділяється узгодженості входів і виходів різних процесів, зменшенню проблем, що виникають на стиках підрозділів. Такий підхід передбачає перехід у ВНЗ від управління підрозділами до управління процесами, що забезпечує безперервність їх управління у межах системи. Процесний підхід $€$ міжфункціональним підходом, який об'єднує в певних процесах окремі фрункції та спрямовує їх на кінцеві результати діяльності, а також дозволяє оцінити освітню діяльність з точки зору можливостей ВНЗ та рівня досягнення в процесі підготовки фрахівців заздалегідь визначених результатів. Головною перевагою процесного підходу $є$ безперервність управління, яку він забезпечує у межах системи процесів [8, 9].

На сучасному етапі необхідною умовою якості підготовки фрахівців фрармацевтичної галузі $є$ рівень компетентності випускника ВНЗ та рівень компетентності НПП, тому одним із вагомих методологічних підходів при побудові СЯВФО є компетентнісний. Компетентнісний підхід дозволяє перейти від орієнтації освіти на відтворення знання до застосування й організації знання, покласти в основу стратегію підвищення мобільності випускників у процесі працевлаштування та орієнтувати діяльність випускників на розмаїття

ISSN 2312-0967. Фармацевтичний часопис. 2016. № 3 
профресійних і життєвих ситуацій. Компетентністний підхід також слід застосовувати до розробки нових галузевих стандартів вищої освіти, з переходом від оцінки знань до оцінки та визначення рівня компетентності $[10,11]$.

Аксіологічний підхід до управління якістю спрямований на оцінку загальнолюдських, громадянських та професійних цінностей випускників. Саме це є підґрунтям структури та змісту СЯВФО. Функціональний підхід передбачає управління взаємопов'язаними процесами як системою для досягнення поставлених цілей, що базується на плануванні, організації, мотивації, контролі та регулюванні якості [12].

Врахування сутності й специоріки наведених наукових підходів сприяє розробці методологічних засад сучасної СЯВФО.

У результаті наукового пошуку проведено узагальнений аналіз визначених наукових підходів, що дозволив виявити підстави до їхньої систематизації та об'єднання у такі групи:

- фрункціональні підходи, які спрямовані на забезпечення якості освітньої діяльності на загальному рівні управління ВНЗ та визначають його окремі функції (результативний, діяльнісний, соціокультурний, нормативно-орієнтований, ресурсний, інституційний, праксеологічний, функціональний);

- когнітивні підходи, що акцентують увагу на оцінці компетентностей здобувачів освіти та активній участі учасників освітнього процесу в ньому, враховують індивідуальні та особистісні якості здобувачів освіти та вимоги споживачів освітніх послуг (компетентнісний, особистісно-орієнтований, критеріально-оріентований, середовищний, акмеологічний, профресіограсрічний, партисипативно-інтерактивний, герменевтичний, мотиваційний);

- фрормувальні підходи, які спрямовані на забезпечення якості умов освітньої діяльності для реалізації компетентнісного підходу (контекстний, репутаційний, персоніфрікований, фрасилітаційний, інфрормаційний, рефлексивний, інноваційний, технологічний, інтегративний);

- підходи, які визначені методологією загального менеджменту якості, міжнародних стандартів і моделей якості освіти (синергетичний, детермінаційний, комплексний, системний, процесний, ситуаційний, аксіологічний).

Наступним кроком досліджень для визначення доцільності застосування визначених наукових підходів при орормуванні СЯВФО нами було проведено опитування працівників ВНЗ, які займаються підготовкою фрахівців фрармації.

Для проведення дослідження методом експертних оцінок були залучені компетентні науково-педагогічні працівники ВНЗ України, які теоретично й практично володіють питаннями управління якістю у вищій освіті, мають досвід науково-педагогічної діяльності понад 10 років і мають вчене звання доктора й кан- дидата наук. Загальна кількість експертів склала 67 чоловік.

У досліджені прийняли участь НПП провідних медичних і фрармацевтичних ВН3: Національний фрармацевтичний університет - 30; Національний медичний університет ім. О. О. Богомольця - 10; Запорізький державний медичний університет - 8; Львівський національний медичний університет імені Д. Галицького - 7; Донецький національний медичний університет ім. Горького - 5; Тернопільський державний медичний університет - 7 .

Загальний аналіз показав відсотковий розподіл на думку експертів використання важливості і доцільності досліджуваних наукових підходів для забезпечення якості вищої фрармацевтичної освіти наступним чином (рис. 1).

Результати опитування показали, що найбільш вживаними для забезпечення якості вищої фрармацевтичної освіти, на думку експертів, є такі підходи: нормативно-орієнтований, інформаційний, ресурсний, технологічний, мотиваційний, критеріально-орієнтований, ситуаційний, особистісно-орієнтований, акмеологічний, соціокультурний, гуманістичний, персоніфікований, професіографічний, інноваційний, рефрлексивний, репутаційний, діяльнісний (від 70 до 100\%).

Експерти мають незначний досвід у використанні інституційного, комплексного, середовищного, результативного, детермінаційного, партисипативно-інтерактивного, інтегративного (від 47 до 54\%).

Тільки починають використовуватись для забезпечення якості вищої фрармацевтичної (медичної) освіти такі наукові підходи: системний, компетентнісний, процесний, аксіологічний, синергетичний, насамперед, у тих ВН3, що запровадили СУя (від 7 до 37\%).

I взагалі у експертів немає досвіду використання контекстного, фрасилітаційного, герменевтичного підходів для забезпечення якості вищої фрармацевтичної (медичної) освіти.

За результатами експертного оцінювання застосування різних наукових підходів для забезпечення якості вищої фармацевтичної (медичної) освіти для подальшого вивчення доцільності їх використання при побудові СЯВФО, а також враховуючи різноманітність та всебічність досліджуваних наукових підходів вважаємо за доцільне формування єдиного методологічного концепту побудови СЯВФО.

Методологічний концепт визначає загальну стратегію взаємодії використовуваних наукових підходів, цілей, методів, інструментів, фракторів впливу для побудови, впровадження і фрункціонування СЯВФО і реалізації її мети (рис. 2).

Проведене дослідження дає підстави стверджувати, що спираючись на запропонований методологічний концепт побудови та фрункціонування СЯВФО

ISSN 2312-0967. Pharmaceutical review. 2016. № 3 
Фармацевтична освіта

Pharmaceutical education

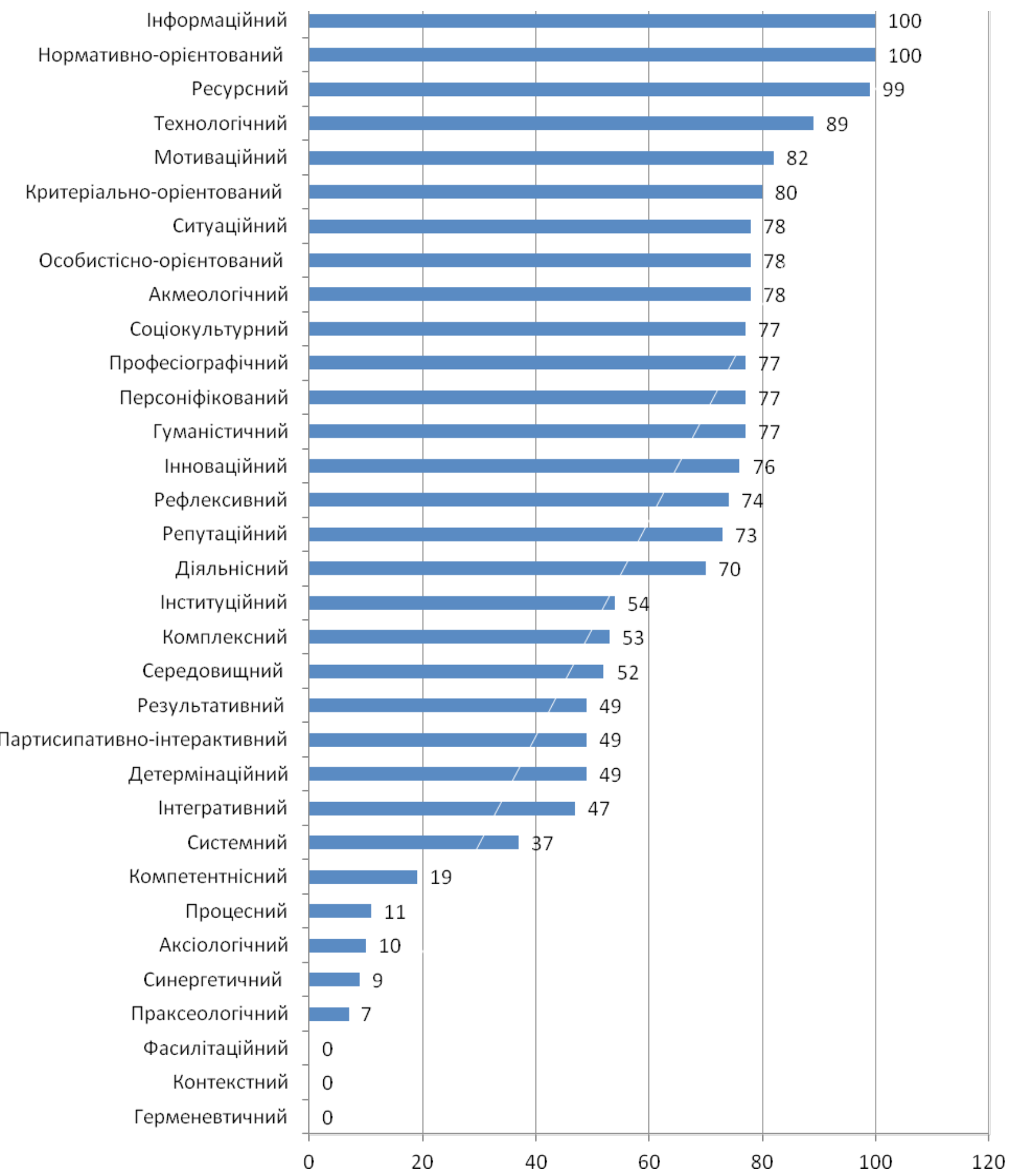

Рис. 1. Розподіл використання наукових підходів для забезпечення якості вищої фармацевтичної освіти (\%).

на основі інтеграції визначених наукових підходів насамперед маємо можливості для:

- створення цілісного науково-методичного підґрунтя побудови СЯВФО;

- формування ефективних алгоритмів впрова- дження, фрункціонування, контролю та поліпшення СЯВФО;

- належного та прозорого управління СЯВФО 3 боку держави, керівництва ВНЗ та споживачів освітніх послуг.

ISSN 2312-0967. Фармацевтичний часопис. 2016. № 3 


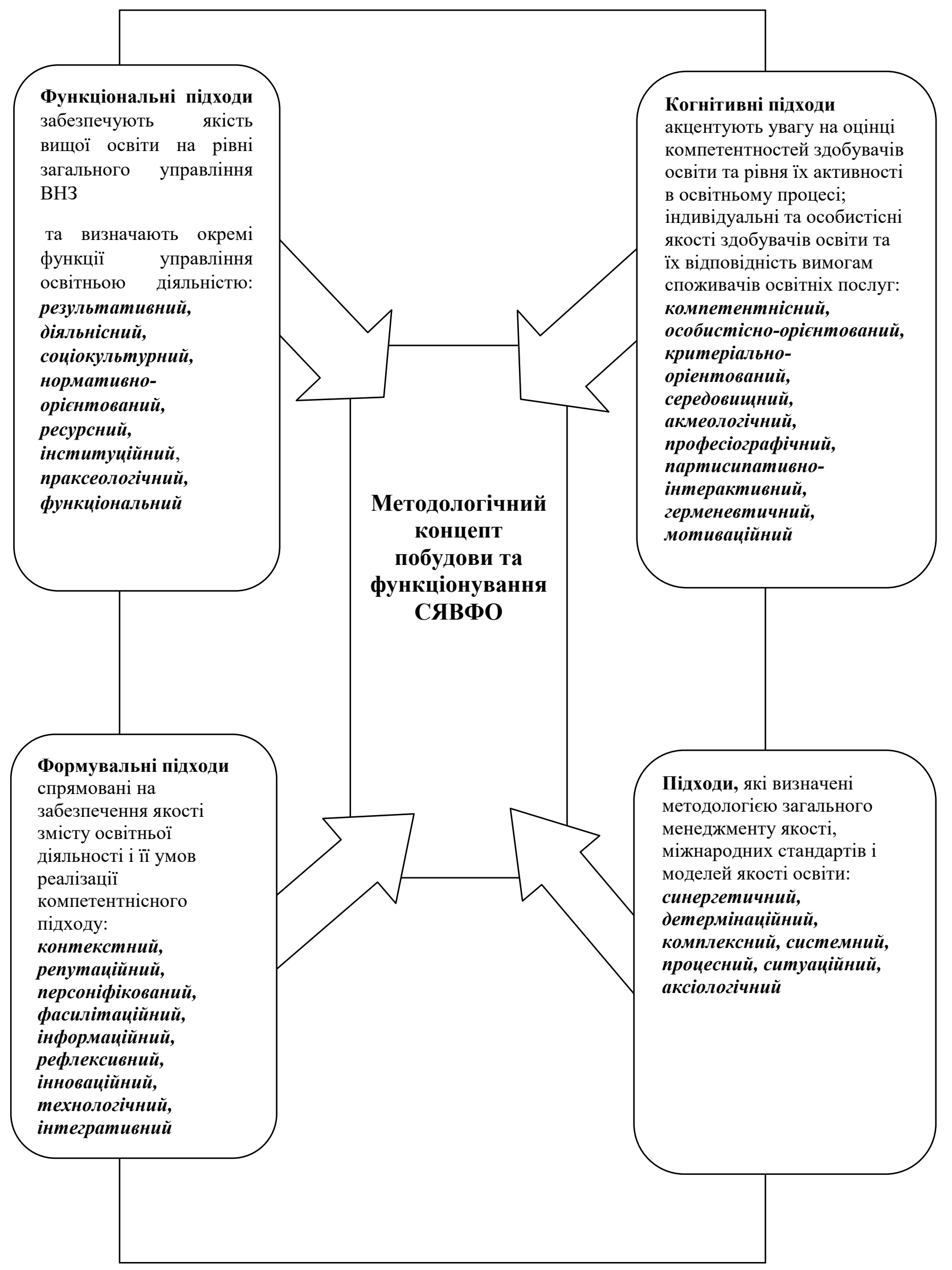

Рис. 2. Методологічний концепт побудови та функціонування СЯВФО.

ISSN 2312-0967. Pharmaceutical review. 2016. № 3 
Висновки. У контексті проведеного дослідження можна констатувати, що запропонований методологічний концепт побудови та фрункціонування СЯВФО є сукупністю взамопов'язаних наукових підходів, згрупованих у такі основні групи: фрункціональні, когнітивні, аспектні та підходи, що ґрунтуються на методології загального менеджменту якості і здатні забезпе- чити єдність, взаємодію цілісність та фрункціонування всіх структурних компонентів СЯВФО.

Виконане дослідження не вичерпує всіх аспектів проблеми і до перспективних напрямів подальших досліджень слід віднести питання документального, методичного та інформаційного забезпечення СЯВФО та системи моніторингу якості вищої фрармацевтичної освіти.

\title{
Список літератури
}

1. Вербицкий А. А. Контекстное обучение: теория и технологии / А. А. Вербицкий // Новые методы и средства обучения. - 2009. - № 2. - С. 51-54.

2. Наукові підходи до педагогічних досліджень : колективна монографрія / за заг. ред. В. І. Лозової. Харків : Вид-во Віровець А. П. «Апострофр», 2012. - 348 с. 3. Масич С. Ю. Методологічні підходи як підґрунтя становлення системи підготовки викладача вищого навчального закладу // Збірн. наук. праць «Педагогіка та психологія». - Харків, 2014. - Вип. - № 46. - С. 86-96. 4. Дубасенюк О. А. Концептуальні підходи до професійно-педагогічної підготовки сучасного педагога. - Житомир : Вид -во ЖДУ ім. І. Франка, 2011. - 114 с

5. Шапран Ю. П. Концептуальні підходи до створення інноваційного освітнього середовища / Ю. П. Шапран // Вісник Інституту розвитку дитини. - К. : НПУ імен М. П. Драгоманова, 2010. - Вип. 11. - С. 121-124.

6. Корчагіна Г. А. Методичний підхід до формування та оцінювання професійної культури управлінського персоналу / Г. А. Корчагіна // Вісник Одеського національного університету. Серія: Економіка. - Одеса : ОНУ ім. Мечникова, 2014. - Т. 19, Вип. 3/2. - С. 100-104.

7. Формування професійної компетентності майбутніх срахівців на основі інтегративного підходу [текст] : метод. реком. / І. М. Козловська, Я. М. Собко, О. О. Стечкевич та ін. - Львів : Сполом, 2012. - 64 с.

8. Зінченко В. О. Методологічні засади управління якістю вищої освіти [Електронний ресурс] - Режим доступу : http:// www.nbuv.gov.ua/portal/Soc_Gum/Gnvp/2011_58_1/3.pdf,;

9. Дмитриченко М. Ф. Концептуальні засади управління якістю вищої освіти в контексті фундаменталізації просресійної підготовки у вищих навчальних закладах України / М. Ф. Дмитриченко, О.М.Язвінська // Вісник НТУ. - К. : НТУ. - 2012. - Вип. 26. - С. 24-30.

10. Кайдалова Л. Г. Професійна підготовка фрахівців фрармацевтичного профрілю у вищих навчальних закладах : монограсрія / Л. Г. Кайдалова. - Х. : НФаУ, 2010. - 364 с.

11. Толочко В. М. Наукове обґрунтування та розробка моделей компетенцій спеціалістів фрармації [Текст] : Методичні рекомендації. - К., 2009. - 23 с.

12. Богма О. С. Сучасні підходи до побудови системи управління якістю продукції на вітчизняних підприємствах вісник ЖДТУ / О. С. Богма, В. В. Ярмош. -2012. - № 4 (62)

- Серія: Економічні науки - С. 274-276.

\section{НАУЧНО-ТЕОРЕТИЧЕСКОЕ ОБОСНОВАНИЕ МЕТОДОЛОГИЧЕСКОГО КОНЦЕПТА ПОСТРОЕНИЯ СИСТЕМЫ КАЧЕСТВА ВЫСШЕГО ФАРМАЦЕВТИЧЕСКОГО ОБРАЗОВАНИЯ}

\author{
А. В. Кайдалова, О. В. Посылкина \\ Национальный фрармацевтический университет, Харьков
}

Резюме: в статье осуществлен научно-теоретический анализ подходов и обоснование методологического концепта построения и функционирования системы качества высшего фрармацевтического образования.

Ключевые слова: система качества высшего фрармацевтического образования, методологический концепт, научные подходы к обеспечению качества.

\section{SCIENTIFIC-THEORETICAL SUBSTANTIATION OF THE METHODOLOGICAL CONCEPT OF BUILDING A QUALITY SYSTEM OF HIGHER PHARMACEUTICAL EDUCATION}

\author{
A. V. Kaydalova, O. V. Posylkina \\ National University of Pharmacy, Kharkiv
}

Summary: the article presents the theoretical analysis of the approaches and rationale of the methodological concept of construction and operation of the quality system of higher pharmaceutical education.

Key words: quality system of higher pharmaceutical education, methodological concept, scientific approaches to quality assurance.

Отримано 06.07.2016

ISSN 2312-0967. Фармацевтичний часопис. 2016. № 3 